\title{
Hubungan Remunerasi dan Motivasi Kerja dengan Kepuasan Kerja Perawat di RS PKU Muhammadiyah Gamping
}

\author{
Elmira Apriliani ${ }^{1}$, Nur Hidayah ${ }^{2}$ \\ ${ }^{1,2}$ Program Studi Manajemen Rumah Sakit, Program Pasca Sarjana, Universitas Muhammadiyah Yogyakarta, Jalan Lingkar \\ Selatan, Tamantirto, Kasihan, Bantul, Yogyakarta, 55183 ${ }^{12}$ \\ Correspondence email: elmiraprilia@ymail.com
}

\begin{abstract}
Abstrak. Remunerasi atau kompensasi, yang merupakan bagian dari manajemen imbalan, dapat menjadi pendorong bagi karyawan untuk bekerja dan mempengaruhi moral serta motivasi pegawai. Penelitian ini bertujuan untuk menganalisa pengaruh remunerasi dan motivasi kerja terhadap kepuasan kerja perawat di RS PKU Muhammadiyah Gamping. Penelitian ini merupakan penelitian kuantitatif dengan pendekatan cross sectional. Sampel penelitian berjumlah 123 orang yang dipilih melalui proportional random sampling, sedangkan metode pengambilan data melalui kuesioner. Analisa data penelitian ini menggunakan analisis jalur (path analysis). Hasil penelitian menunjukkan variabel remunerasi memiliki pengaruh positif signifikan terhadap kepuasan kerja $(\mathrm{p}=0,007)$, motivasi kerja $(\mathrm{p}=0,00)$ dan motivaasi kerja memiliki pengaruh positif signifikan terhadap kepuasan kerja $(\mathrm{p}=0,001)$. dari hasil uji analisis jalur juga didapatkan pengaruh langsung remunerasi terhadap kepuasan kerja perawat lebih besar dibandingkan pengaruh tidak langsungnya. Optimalisasi motivasi dan kepuasan perawat di bangsal rawat inap RS PKU Muhammadiyah Gamping dalam pelaksanaan proses keperawatan terhadap pasien dapat ditingkatkan melalui penyesuaian remunerasi atau kompensasi yang diberikan oleh rumah sakit.
\end{abstract}

Kata kunci: kepuasan kerja; motivasi kerja; remunerasi

Abstract. Remuneration or reward, which is part of compensation management, may affect the morale and motivation of employees to do a better work performance. This research aimed to analyze the correlation between remuneration and work motivation with nurses' job satisfaction in PKU Muhammadiyah Gamping Hospital. This study was a quantitative one with cross sectional approach. The sample of this study consisted of 123 nurses which was selected using proportional random sampling method. Questionnaires were used to gather data and the result analyzed with path analysis method. The result showed that remuneration variable had a positive and significant influences on nurses' job satisfaction ( $p=0,007)$, work motivation ( $p=0,003)$ while work motivation had a positive significant influences on nurses' job satisfaction $(p=0,001)$. The result of path analysis indicated that the direct influence of remuneration on nurses' job satisfaction is higher compared to its indirect influence. Optimalization of nurses' work motivation and job satisfaction on the implementation of a professional nursing care in PKU Muhammadiyah Gamping hospital can be improved by adjusting the remuneration or compensation of their work services.

Keywords: job satisfaction; remuneration; work motivation

\section{PENDAHULUAN}

Dalam pengelolaan rumah sakit, pengelolaan sumber daya manusia merupakan hal yang terpenting. Hal itu karena sangat bervariasinya jenis tenaga di rumah sakit, tujuan kerja yang beragam, tingkat motivasi, komitmen, dan loyalitas yang berbeda-beda, yang kesemuanya tersebut akan mempengaruhi kepuasan kerja tiap-tiap individu.

Remunerasi atau kompensasi, yang merupakan bagian dari manajemen imbalan, dapat menjadi pendorong bagi perawat untuk bekerja dan mempengaruhi moral serta motivasi perawat. Dalam menetapkan remunerasi (manajemen imbalan), rumah sakit perlu memperhatikan prinsip keadilan. Kemungkinan yang akan dirasakan oleh perawat saat menerima imbalan jasa dari rumah sakit antara lain yaitu gaji yang diterima kurang atau melebihi dari bobot pekerjaan yang diberikan dan gaji tersebut sesuai dengan bobot pekerjaannya. Jika yang terjadi adalah mereka merasa gaji yang diterima kurang dari bobot pekerjaannya, maka karyawan akan merasa adanya ketidakadilan.

Pemberian imbalan jasa yang adil dan layak akan mempengaruhi motivasi kerja bagi perawat dan diharapkan menciptakan kepuasan kerja yang baik sehingga tercapai tujuan dari pelayanan rumah sakit yang berkualitas.

Mengingat akan kepentingan motivasi tersebut, pihak rumah sakit perlu melakukan usaha pemotivasian kepada karyawan melalui cara-cara tertentu sesuai dengan kebijakan rumah sakit, sehingga motivasi para karyawan tetap stabil.

RS PKU Muhammadiyah Gamping merupakan rumah sakit tipe $\mathrm{C}$ milik Persyerikatan Muhammadiyah dengan status akreditasi paripurna. Berdasarkan hasil pengamatan dalam studi pendahuluan peneliti, banyaknya pasien setiap hari yang datang ke RS PKU Muhammadiyah Gamping membuat karyawan semakin sibuk sehingga karyawan mudah lelah dalam melakukan pekerjaan, ditambah lagi gaji yang didapat tidak sebanding dengan pekerjaannya. 
Penelitian ini memiliki tujuan untuk menganalisis hubungan antara remunerasi dan motivasi kerja dengan kepuasan kerja di RS PKU Muhammadiyah Gamping.

\section{METODE}

Pada penelitian ini akan dilakukan metode penelitian analitik kuantitatif yang diambil secara cross sectional. Penelitian ini akan dilaksanakan pada bangsal rawat inap RS PKU Muhammadiyah Gamping.

Variabel yang digunakan dalam penelitian ini adalah variabel bebas dan variabel terikat. Variabel bebas penelitian ini antara lain remunerasi dan motivasi kerja, sedangkan variabel terikatnya adalah kepuasan kerja perawat.

Penelitian ini dilaksanakan pada bulan Juni 2019. Populasi penelitian ini adalah seluruh perawat pelaksana yang bekerja di bangsal rawat inap RS PKU Muhammadiyah Gamping. Sampel penelitian ini berjumlah 123 orang perawat dari 8 bangsal rawat inap, ruang ICU dan ICCU.

\section{HASIL DAN PEMBAHASAN \\ Hasil \\ Deskripsi Variabel Penelitian}

Hasil penelitian ini antara lain analisis univariat yang terdiri dari distribusi frekuensi variabel bebas (remunerasi dan motivasi kerja) dan variabel terikat (kepuasan kerja perawat), kemudian analisis multivariat untuk mengetahui pengaruh antar variabel.

Hasil statistik deskriptif pada variabel penelitian menunjukkan bahwa nilai mean atau rata - rata skor pada tiap variabel berada dalam kategori puas untuk remunerasi dan kepuasan kerja, serta baik untuk motivasi kerja.

Tabel 1. Hasil Analisis Deskriptif Variabel Penelitian

\begin{tabular}{lllll}
\hline \multicolumn{1}{c}{ Variabel } & Min & Max & Mean & Std. Dev. \\
\hline Remunerasi & 20 & 28 & 22,12 & 1,53 \\
Motivasi Kerja & 42 & 59 & 46,85 & 2,70 \\
$\begin{array}{l}\text { Kepuasan } \\
\text { Kerja }\end{array}$ & 54 & 63 & 58,92 & 1,97 \\
\hline
\end{tabular}

Pada kategorisasi intepretasi skor persentase remunerasi menunjukkan hasil intepretasi puas $=87 \%$, cukup $=13 \%$, dan kurang $=0 \%$; kemudian untuk kategorisasi intepretasi skor persentase motivasi kerja menunjukkan hasil intepretasi baik $=78,05 \%$, cukup $=$ $21,95 \%$, dan kurang $=0 \%$; sedangkan untuk kategorisasi intepretasi skor persentase kepuasan kerja didapatkan hasil inepretasi puas $=88,62 \%$, cukup $11,38 \%$, dan kurang $0 \%$.

\section{Hasil Uji Path Analysis Pengaruh Langsung}

Analisa hubungan pengaruh antar variabel dilakukan dengan analisis jalur. Tujuan dari analisis jalur adalah untuk mengetahui pengaruh langsung dan tidak langsung antar variabel tersebut. Berdasarkan hasil perhitungan analisis jalur didapatkan hasil bahwa variabel remunerasi berpengaruh langsung terhadap variabel kepuasan kerja dengan standardized coefficient beta adalah $\mathrm{p} 1=0,235$ dan nilai signifikansi sebesar 0,007. Variabel motivasi kerja berpengaruh langsung terhadap kepuasan kerja dengan dengan standardized coefficient beta adalah $\mathrm{p} 2=0,301$ dan nilai signifikansi sebesar 0,001. Variabel remunerasi juga berpengaruh langsung terhadap motivasi kerja dengan standardized coefficient beta adalah p3 $=0,268$ dan nilai signifikansi sebesar 0,003 .

Tabel 2. Rangkuman hasil koefisien analisis jalur

\begin{tabular}{lccc}
\hline \multicolumn{1}{c}{$\begin{array}{c}\text { Hubungan } \\
\text { Variabel }\end{array}$} & $\begin{array}{c}\text { Standardized } \\
\text { coefficient beta }\end{array}$ & Nilai t & $\begin{array}{c}\text { Nilai } \\
\text { Sig }\end{array}$ \\
\hline $\begin{array}{l}\text { Remunerasi } \rightarrow \\
\text { kepuasan kerja }\end{array}$ & 0,235 & 2,751 & 0,007 \\
$\begin{array}{l}\text { Motivasi kerja } \rightarrow \\
\text { kepuasan kerja }\end{array}$ & 0,301 & 3,514 & 0,001 \\
$\begin{array}{l}\text { Remunerasi } \rightarrow \\
\text { motivasi kerja }\end{array}$ & 0,268 & 3,063 & 0,003 \\
\hline
\end{tabular}

\section{Pengaruh Tidak Langsung}

Berdasarkan hasil pengujian pengaruh tidak langsung remunerasi terhadap kepuasan kerja perawat melalui motivasi kerja sebagai mediasi, didapatkan bahwa nilai pengaruh langsung adalah $\mathrm{p} 1=0,235$ dan pengaruh tidak langsungnya adalah 0,315 .

Tabel 3. Pengaruh Tidak Langsung dan Pengaruh Total

\begin{tabular}{lccc}
\hline Keterangan & $\begin{array}{c}\text { Pengaruh } \\
\text { Langsung } \\
\text { (a) }\end{array}$ & $\begin{array}{c}\text { Pengaruh } \\
\text { Tidak } \\
\text { Langsung } \\
\text { (b) }\end{array}$ & $\begin{array}{c}\text { Pengaruh } \\
\text { Total } \\
\text { (a) }\end{array}$ \\
\hline Remunerasi & $\mathrm{p} 1=0,235$ & $\mathrm{p} 3 \times \mathrm{p} 2=$ \\
& & $0,268 \times 0,301$ \\
& & 0,080 \\
& &
\end{tabular}

\section{Pembahasan \\ Remunerasi berpengaruh signifikan terhadap kepuasan kerja perawat}

Hasil uji Path Analysis antara variabel remunerasi dan kepuasan kerja menunjukkan pengaruh positif dan signifikan. Pengaruh positif berarti pengaruh remunerasi terhadap kepuasan kerja adalah searah. Semakin baik remunerasi yang diberikan rumah sakit, maka kepuasan kerja perawat akan semakin meningkat

Hal ini sejalan dengan penelitian yang dilakukan oleh Kalalo et al (1), yang menunjukkan hubungan yang bermakna antara kompensasi dengan kepuasan kerja perawat di RSU Bethesda Tomohon dengan perbandingan proporsi perawat 2,4 kali kurang puas dalam bekerja apabila kompensasi yang diberikan kurang. Lestari dan Tjahjono (2) menyatakan bahwa fokus utama perawat dalam bekerja adalah memperoleh kesejahteraan dalam hal kompensasi. 


\section{Motivasi kerja berpengaruh signifikan terhadap kepuasan kerja perawat}

Motivasi kerja menciptakan suatu kondisi kerja yang mendorong semangat untuk bekerja dan pada akhirnya akan mempengaruhi tingkat kepuasan kerja (3).

Hasil uji hipotesis menunjukkan pengaruh positif motivasi kerja terhadap kepuasan kerja. Positif tampak dari koefisien regresi motivasi kerja sebesar 0,301 dengan signifikansi sebesar 0,001. Pengaruh positif artinya pengaruh motivasi kerja searah dengan kepuasan kerja perawat. Motivasi kerja perawat yang tinggi akan berpengaruh terhadap kepuasan kerja yang tinggi pula.

Hasil penelitian ini sejalan dengan yang diungkapkan Wahyuni (3) bahwa terdapat pengaruh motivasi kerja terhadap kepuasan kerja perawat di unit rawat inap Santosa Hospital Bandung Central. Penelitian Sudan (2016) juga menyebutkan bahwa motivasi kerja memiliki hubungan yang positif dengan kepuasan kerja perawat di Rumah Sakit Umum Daerah Sumedang (4).

\section{Remunerasi berpengaruh signifikan terhadap motivasi kerja perawat}

Remunerasi merupakan suatu bentuk imbalan atau balas jasa yang diberikan oleh rumah sakit kepada tenaga medis atas pelayanan yang diberikan terhadap pasien (5). Sistem remunerasi yang baik untuk perawat memberikan dampak yang positif terhadap ketahanan bekerja perawat dan meningkatkan kepuasan maupun motivasi kerja mereka (6).

Hasil penelitian ini menunjukkan pengaruh positif dan signifikan remunerasi terhadap motivasi kerja. Hal ini berarti bahwa remunerasi yang diberikan rumah sakit memberikan dampak nyata terhadap motivasi kerja perawat, apabila remunerasi yang diberikan sesuai dengan harapan perawat maka motivasi kerja mereka akan meningkat, begitu pula dengan sebaliknya.

Penelitian yang dilakukan oleh Negussie (7), sejalan dengan penelitian ini, menyatakan bahwa diantara variabel - variabel yang mempengaruhi motivasi kerja, kompensasi merupakan variabel yang paling signifikan dibandingkan dengan variabel lain seperti pengakuan oleh atasan. Kompensasi yang rendah juga menyebabkan berkurangnya tingkat tenaga kesehatan yang bekerja di suatu daerah.

\section{Motivasi kerja berpengaruh sebagai intervening antara pengaruh remunerasi terhadap kepuasan kerja}

Berdasarkan hasil pengujian variabel intervening, didapatkan bukti bahwa variabel motivasi kerja tidak menjadi variabel intervening. Hasil tersebut menunjukkan bahwa pengaruh langsung remunerasi terhadap kepuasan kerja perawat di ruang rawat inap RS PKU Muhammadiyah Gamping lebih kuat dibanding dengan pengaruh tidak langsung nya melalui motivasi kerja. Hasil penelitian ini berbeda dengan yang didapatkan oleh Kalalo et al (1), yang membuktikan bahwa remunerasi meningkatkan kepuasan kerja perawat melalui motivasi kerja.

Berdasarkan teori kepuasan kerja dari Robbins (8) disebutkan bahwa kepuasan terhadap imbalan, dimana indikatornya meliputi imbalan ekstrinsik yaitu gaji, tunjangan, pension, dan asuransi; dan imbalan intrinsik yaitu keamanan dalam bekerja dan kesempatan masa depan, merupakan faktor utama untuk mencapai kepuasan kerja. Kalalo et al (1) menyebutkan bahwa seseorang yang memiliki motivasi yang tinggi belum tentu merasa puas dengan pekerjaannya, tetapi semakin tinggi tingkat kepuasan kerja seseorang dapat meningkatkan motivasinya dalam bekerja.

\section{SIMPULAN}

Penelitian ini menunjukkan bahwa Remunerasi dan motivasi kerja merupakan hal yang sangat penting untuk mencapai kepuasan kerja perawat di RS PKU Muhammadiyah Gamping. Optimalisasi motivasi dan kepuasan perawat di bangsal rawat inap RS PKU Muhammadiyah Gamping dalam pelaksanaan proses keperawatan terhadap pasien dapat ditingkatkan melalui penyesuaian remunerasi atau kompensasi yang diberikan oleh rumah sakit.

\section{DAFTAR PUSTAKA}

Kalalo, C. N., Sjattar, E. L., \& Natzir, R. (2018). Correlation Between Compensation and Work Satisfaction with Nurses' Performance through Motivation in Bethesda Public Hospital of Tomohon. Indonesian Contemporary Nursing Journal (ICON Journal), 3(1), 12-21.

Lestari, E., \& Tjahjono, H. K. (2013). Pengaruh Keadilan Kompensasi Terhadap Kepuasan Kerja Perawat Di RSUD Sultan Imanuddin Pangkalan Bun Kalimantan Tengah. JMMR (Jurnal Medicoeticolegal dan Manajemen Rumah Sakit), 2(1).

Wahyuni, S. (2017). Pengaruh Kompensasi dan Motivasi Kerja terhadap Kepuasan Kerja serta Implikasinya pada Kinerja Perawat (Studi Pada Perawat di Unit Rawat Inap Santosa Hospital Bandung Central) (Doctoral dissertation, UNPAS)4. Menteri Kesehatan Republik Indonesia. Peraturan Menteri Kesehatan RI Nomor 269/MENKES/PER/III/2008. 2008 hal. 2-2.

Sudan, Y. (2016). Pengaruh Motivasi dan Disiplin Kerja terhadap Kepuasan Kerja serta Implikasinya pada Kinerja Perawat di Rumah Sakit Umum Daerah Kabupaten Sumedang. (Doctoral dissertation, UNPAS).

Hidayat, Y. (2016). Pengaruh Sistem Remunerasi dan Lingkungan Kerja terhadap Motivasi Kerja dan Dampaknya terhadap Kinerja Perawat di RS Paru DR. HA Rotinsulu Bandung (Doctoral dissertation, UNPAS). 
Elmira Apriliani dan Nur Hidayah, Hubungan Remunerasi dan Motivasi Kerja dengan Kepuasan Kerja Perawat di RS PKU Muhammadiyah Gamping

Yetti, K., \& Gayatri, D. (2019). Remuneration Satisfaction to Improve Work Motivation of Nurses: A Cross-Sectional, Descriptive Analysis Study. Journal of International Dental and Medical Research, 12(1), 291-298.

Negussie, N. (2012). Relationship between rewards and nurses' work motivation in Addis Ababa hospitals. Ethiopian journal of health sciences, 22(2).

Robbins, S. P. (2013). Organizational Behavior. United States of America: Pearson Educational Inc. 